\title{
The Indonesian Electoral System Development: Does Papua Need Local Parties?
}

\author{
Abdul Basid Fuadi ${ }^{1}$ and Zaka Firma Aditya ${ }^{2}$ \\ \{abdul.basid@mkri.id'1, zaka.firma@mkri.id² \\ Center for Research and Case Analysis, The Constitutional Court of the Republic of Indonesia ${ }^{12}$
}

\begin{abstract}
Indonesia has three special region and one capital city, namely Aceh, Yogyakarta, Papua, and Jakarta. Each special region has its unique and privileges. The enactment of Law Number 21 the year of 2001 has proven that the state acknowledged the existence of Papua as special region. This regulation gives Papua privileged in special autonomy to manage its region including in the process and mechanism of General Election, as Indonesia Constitution 1945 stipulated the freedom of speech, gather, and protect the rights of every citizen to fight for their rights communally to develop the society and state. The problem is, there was a case in 2019 where a Local Political Party in Papua was rejected to join the General Election due to the lack of Local Regulation specifically regulating the formation of Local Parties in Papua. Meanwhile, in the 2019 General Election, Aceh (as another Special Region) has one Local Political Party that participated the election. It seems that there is an inequal position amongst special region. This paper aims to analyze the legal reasoning and urgency of the local parties' formation in Papua because it has the privileges to do so. The research method of this paper uses statute and conceptual approach.
\end{abstract}

Keywords: Local Party; Papua; Special Region; Aceh; Asymmetric Decentralization

\section{Introduction}

A political party is an organized group whose members have the same orientation, values, and ideals that have political power and seize political position by constitutional means to carry out its program. [1] In democracies, it is difficult to deny the fundamental role and the existence of political parties, because it has become a bridge between the state and citizens. Besides, the presence of political parties also has checks and balances between branches of power. [2] To the functions of political parties, there are four essential roles of political parties, namely, (1) means of political communication; (2) points of political socialization; (3) political recruitment; (4) conflict manager [3].

The importance of the existence of political parties has recognized since Indonesia was the first form. In the early days of his reign, through Maklumat X Vice President Moh. Hatta stated:

"In connection with the Central National Committee Workers' Agency's proposal to the government to give the people as wide as possible the opportunity to establish political parties, with the restriction that these parties should expand our struggle to defend the independence and ensure the security of society. The government affirms its stance taken some time ago that: (1) The government likes the emergence of political parties because it can lead to an orderly way all the schools of understanding in society. (2) The government hopes that the 
parties will be organized before the election for members of the People's Representative Bodies is held in January 1946".[4]

From a legal perspective, establishing a political party is a form of freedom of expression and freedom of association. Both have an interdependent relationship; freedom of expression will be paralyzed without freedom of association. Meanwhile, freedom of association is meaningless without freedom of expression. Article 20 of the Universal Declaration of Human Rights protects and guarantees the establishment of political parties, with the limitation that they are democratic and peaceful.

This provision allows the formation of local or region-based parties. And many countries also have political parties which are based or regional, for example, Canada, Spain, Germany and Finland. Associated with the establishment of local political parties in Indonesia, it is also the embodiment of freedom of assembly, association and expression. However, can the Indonesian political system accept the existence of local political parties? The next problem is whether the acceptance or rejection is general throughout Indonesia, or is it specific?

Indonesia knows local political parties, namely in Aceh Province. As a follow-up to the Helsinki MoU, Law Number 11 of 2006 concerning Aceh Province passed. Twenty articles regulate local political parties in Aceh, from their formation to their supervision. Since the law enacted, local parties have contested three times in general elections and succeeded in sending representatives to the Aceh People's Representative Council, Aceh Regional People's Representative Council.

Meanwhile, in Papua's context, the establishment of local political parties that have historically proven to draft the Papua Special Autonomy which uses the phrase Local Political Parties in Article 25 of the Papua Special Autonomy bill. Unfortunately, it is not known, or at least no local Papuan parties are contesting the elections. This fact considered to be dualism and discriminatory attitude from the legislators against the population in Papua Province and the Aceh Province population. Both of which formally apply special autonomy following the order of the TAP MPR RI Number IV/MPR/1999, but it is materially different in the regulation about the right to form a political party.

This paper aims to answer whether local political parties can be established in Papua as in Aceh to answer whether Papua needs local political parties to strengthen its democracy. In order to explain the above, this study will discuss successively the concept of asymmetric decentralization, local (regional) political parties in several countries, local political parties in Indonesia and the constitutionality of local parties in Papua according to the Constitutional Court Decision.

\section{Local Political Parties in Several Countries}

The choice became the agreement of the funding founders who were members of the BPUPKI who later became PPKI was to establish an Indonesian in the form of a unitary state and a form of republican government as referred to in Article 1 paragraph (1) of the 1945 Constitution. However, understanding the principle of a unitary state cannot be separated from the distribution arrangement area. It is intended to balance the centralistic nature of the unitary system in regional management in Indonesia. On the other hand, due to the Indonesian is eenheidstaat, it will not have any regions in its environment that are country as well [5].

Indonesia is a unitary state, in terms of running the relationship between central and local government adheres to the principle of decentralization in its implementation. Decentralization 
provides flexibility for local governments to regulate their affairs. The principle of decentralization is the essence of regional autonomy. Ni'matul Huda when explaining autonomy, states that the relationship of authority between the central and regional governments, among others, relates to the way the division of government administration affairs or how to determine regional household affairs [6].

The word 'autonomy' itself is a fragment of two Greek words, namely autos, which means itself and nomos, which means law. Autonomy means making one's laws (zelfwetgeving). But in its development, the conception of autonomy, also, to connote zelfwetgeving (make by laws), also mainly covers zelfbestuur (self-government). C.W. Van der Pot understands the concept of regional autonomy as eigen huishounding (running his household) [7].

Regional autonomy with the principle of decentralization was born at the demands of elements of society in the regions - the demand based on the treatment applied by the government during the New Order era. During the New Order era, regions were only used as the implementing object of the central government. As a result of this centralistic nature, the region is only used as a tool by the central government, to implement whatever has been determined by it without any consideration from the regional government or the local community.

As a result of the amendments to the 1945 Constitution, the elaboration of the regional government system in Article 18 of the 1945 Constitution was explained. Bagir Manan stated that both the structure and substance of the changes were fundamental. Structurally, Article 18 (old) was entirely replaced by a new one. [8] Apart from regional governments' existence in the Unitary State, there are also regional governments special or special. A special or special regional government explicitly stated in Article 18B of the 1945 Constitution. The principles in Article 18B of the 1945 Constitution state recognition of regional government special or special and the principle of indigenous peoples' existence and traditional rights.

Theoretically and at an empirical level, asymmetric autonomy can be interpreted as an alternative policy by the central government in a country facing enormous inequality suffered by certain regions, both in terms of economic, demographic, social pluralism, and aspects of welfare. This policy of granting asymmetric autonomy, by giving different treatment, is expected to eventually allow for stronger national coherence or unity due to more specific problems can be resolved peacefully and with far more satisfying results [9].

In a more contemporary context, JPP Fisipol UGM (2010) research shows that there are at least five reasons why asymmetric decentralization should carry out in Indonesia.[10] First, the reason for the conflict and separatist demands. Undeniably, two regions (three Province) are the provinces of Aceh, Papua and West Papua Provinces receive special treatment in the form of special autonomy for the conflict between the area with national governments, among others due to resource conflicts.

If summarized, special autonomy for Aceh and Papua principally consists of: (1) the Special Autonomy funds as compensation for the three provinces can still join the Republic of Indonesia. (2), recognition of local identity embodied in political institutions. [10] In Aceh, the process marked by a new institution that represents customs and religion. In Papua, authority given to Adat and the church. (3), recognition of local symbols such as the flag, language, songs etc. (4), the local political parties. Aceh takes advantage of local parties' momentum by growing local parties and winning elections, while in Papua there is no room for this. (5), there is affirmative action to become a local leader. In Aceh his form by reading the Quran, Papua leaders had Papuans passed by the Papuan People's Assembly, (6) perhaps most importantly, resource-related arrangements. In addition to the special autonomy fund these massive 
numbers, resources management is an issue. Aceh has specific specificities related to the management of resources, such as land, forests and oil exploitation [11]

Second, the reason the nation's capital. This special treatment is given only to Jakarta. [10] Third, historical and cultural reasons. Special Region of Yogyakarta gets preferential treatment given the history of the Revolution and the struggle for independence. It can see this treatment Governor, and Deputy Governor's determination in the province carried out by Parliament. [10] The governor of DIY is the Sultan who reigns, and the Deputy Governor of Yogyakarta is Pakualam who reigns. The determination of the Sultan and Pakualam left to the respective keraton.

These two leaders are not allowed to join political parties. At the district/city level it remains the same as other regions. Fourth, border reasons. According to Tim JPP (JPP-UGM 2010), the border needs to get special treatment in view of its role as a boundary with the neighboring countries. [10] The border area holds an essential function because of the complexity of the problems faced. The border area should be treated as the front page and not the Republic of Indonesia's back yard. Treatment of border areas, for example in West Kalimantan, should be different, for example by requiring the governor to come from the military because of the high potential for border crossers and strengthening education and health infrastructure and services. Details about asymmetries border still need further study.

Fifth, the center of economic development. The geographic area can become a special economic area and should develop to have high economic competitiveness. [10] Regions like Batam can be developed and set up to rival Singapore. The allocation of specificity, for example, concerns import duties and the development of economic development infrastructures such as ports and port systems. The largest port in Indonesia today is Tanjung Priok in Jakarta to meet domestic demand because of its geographical position. If Batam developed with a modern harbor with a good system, it is possible to take advantage of a Singapore port's potential with limited space. Details about asymmetries economic development still need further study.

The granting of different autonomy over one region or region from several regions is a practice of governance that is quite common in political governance in many countries. This experience takes place both in the form of a decentralized unitary state, and federative arrangement. In political science and government, this disproportionate governance pattern is referred to as asymmetrical decentralization, asymmetrical devolution, asymmetrical federalism, or in general asymmetrical intergovernmental arrangements. In principle, various forms of the asymmetrical distribution of power are the policy instruments intended to address two fundamental issues facing a country. The issue of political patterned (including those rooted in the uniqueness and cultural differences) and the question is patterned technocraticmanagerial, namely the limited capacity of an area or a region in carrying out government's essential functions [12].

Asymmetrical arrangement associated with the politics pursued as a policy strategy for maintaining basic political unit boundaries of a country or as an appreciation for the uniqueness of particular cultures. With different levels of success, representation of minorities at the sub-national level and granting special/special status for one region or regional area can encourage groups/regions that demand special/special status to eliminate/minimize violence and maintain territorial integrity.

[13] Practices in other countries show the option of asymmetric decentralization as an alternative policy option. The 1978 Spanish Constitution, for example, was able to make Spain a country with a decentralized system of government, namely by giving regions the right to regulate their regions legally and administratively. The Spanish government grants autonomy 
to regions that have specialized in regional history (historical rights), granting autonomy to the regions in Spain takes different depending on how appropriate the area is to autonomy.

[14] Some regions get autonomy rights without taking a long time, and most of them take longer. It depends on the uniqueness of the area. The Spanish Autonomous Community consists of 17 regions in Spain as well as two autonomous cities in Africa which include: Catalonia, Basque, Galicia, Andalusia, Aragon, Asturias, Castilla La Mancha, Castilla Leon, Valencia, Balearies, Canaries, Cantabria, Extremadura, La Rioja, Madrid, Mureia, Navarre, and two autonomous cities in Africa, Ceuta and Melilla.[14]

Another example from Canada's experience in regulating Quebec's privileges in union with the Canadian Federation. Quebec itself has an autonomous status because most of its population is Francophone (French-speaking) while Canada is an Anglophone (Englishspeaking) country. [15] Whereas in China, Hong Kong and Macau were given special autonomy rights only for 50 years starting from 1997 and 1999 which would end in 2057 and 2059 and after that Hong Kong and Macau would be uninformed again as provinces. [16]

\section{Local Political Parties in Several Countries}

Political parties are part of a country's political system and cannot separate their presence from their roles and functions, which manage constituents and the state. Through political parties, the community (party cadres) can occupy political positions through general elections, which means that they will determine public policy. Therefore, political parties' presence needs to be placed within a broader framework and is not limited to their ideological groups. The good and bad of regeneration and regeneration within political parties will determine the nation's leading candidates' quality. [17]

In general, it can say that a political party is an organized group whose members have the same orientation, values and ideals. The purpose of this group is to gain political power and wrest political position - (usually) by means of the constitution to implement its program, [18] both in the government and who are outside of government. Basically, political parties have the same goal: to build their nation and state. Local political parties have been known since the late 19th and early 20th centuries. Mc Kenzie noted that the British labor party was founded in 1990, among others, by several local labor parties. While in the United States, local political party emerged in 1900 with the establishment of the Home Rule Party of Hawaii to serve the aspirations of Native Hawaiians in the state legislature and Congress. However, this party only lasted until 1912.[19]

A local political party is a political party whose network is limited to a region (province or state) or several regions, but does not cover all provinces (national). According to Abdul Mukthie Fadjar, local political parties are political parties that are based on or rely on their support solely in a region or region within a country.[20] Basically, all functions performed by national political parties are also performed by local political parties. The only difference lies in the level.

England is an example of a country with a bi-party system. In its history, the party in England formed the Ruling Class's competition, which was princes who controlled lands, and Money Man, a group of people who became prosperous due to trade or industry. The princes and landlords called the Tory, while the new class of people who had a lot of money were called the Whigs. The Tory struggle's value is how much it is permissible to maintain the 
ancient, while the Whigs are, on the contrary, how much it is acceptable to change the old to the modern. His party was eventually called the Conservative Party and the Liberal Party. [21]

Apart from national parties, there are also local political parties in England. The legal basis for forming political parties in the UK regulated in the Political Parties, Elections and Referendums Act 2000 (PPERA) as amended by the Political Parties and Elections Act 2009 (PPE Act). The law does not explicitly mention local political parties because it does not recognize the dichotomy of the terms of national and local political parties. There is also no mention of the definition of political parties in the Act on this matter. [22]

In the provisions of the Act, there is no restriction on establishing political parties in the UK with the obligation to nominate candidates in the legislature in all regions of the UK (United Kingdom). Thus, political parties in the UK can only participate in elections at certain local levels by submitting their candidates to the House of Representatives at that level. This provision can be observed in Part II Article 23 Paragraph (2) of the PPERA which states.

The new registers of political parties are:

a. a register of parties that intend to contest relevant elections in one or more of England,

Scotland and Wales (referred to in this Act as 'the Great Britain register'); and

b. a register of parties that inted to contest relevan elections in Northern Ireland (referred to in this Act As 'the Northern Ireland register').

Scotland, whose territory is still part of Great Britain's territorial sovereignty, in practice, the existing local political parties still have aspirations and hopes for independence in the future. That said, because of at least 17 political parties in Scotland, five local parties, such as SNP, SGP, SSP, SEP, and SIP, are still free to determine the principles with which their party aims to gain independence for Scotland.

Also, in Wales, a local political party carries a distinctive Welsh vote called the Party of Wales. The party has an ideology of nationalism and social-democracy and struggles to liberate Wales from England. Meanwhile, in Northern Ireland, there is the UK's largest local political party called the Democratic Unionist Party (DUP). DUP founded on September 30, 1971, with the ideology of unionism (union with the British Empire), populism, national conservatism, and social conservatism. Apart from DUP, which is the largest local political party in the United Kingdom and Northern Ireland, there is also one party that has the goal of forming one Irish, namely Sinn Fein. [23]

In Spain, local political parties strongly developed only in the Basque Country and Catalonia. These two areas have powerful local traditions associated with the development of history and language differences. Local parties in Spain participate in regional and national elections. Convergence and Union (Convergence i Union, CiU) is a coalition of two parties in Catalonia, namely the Democratic Convergence of Catalonia (CDC) and the Democratic Union of Catalonia (UDC). CiU ruled Catalonia for 23 years from 1980 to 2003. [24] In the 2010 elections, CiU returned to lead Catalonia with the new CiU leader, Artur Mas, as Catalonia's regional head. CiU calls itself a Catalan nationalist party even though the Catalonia and Spanish media consider this party to be a moderate nationalist party [25].

\section{Local Political Parties in Indonesia}

In general, local political parties according to their objectives can be divide into three categories, namely: 
a. Minority Rights, local political parties that protect and promote the economic, social, cultural, linguistic and educational rights of certain minority groups. For example, the local political party in Finland, Svenska folkpartiet i Finland (SFP) - (Swedish People's Party of Finland), works to protect ethnic Swedes who are an ethnic minority [26].

b. Obtaining Autonomy, political parties that want autonomy for their region or to increase the level of autonomy that the region already has. It is a common reason for the existence of local political parties [26].

c. Achieve Independence, political parties are explicitly fighting for Independence of their territory and establishing a new country. [26] Generally, it is motivated by the development of a long history, or cultural differences are decisive. Local political parties of this type exist in England's kingdom, namely in Scotland and Wales, which fight for the Independence of these two regions. In Spain, local political parties in Catalonia and the Basque also demanded Independence for the territory. In the province of Quebec (which is predominantly French-speaking because France colonized it) there is also a local political party, the Parti Quebecois, which has a plan of liberating Quebec from the unitary state of Canada (with the national English language).

Local political parties actually existed in Indonesia in the 1955 general elections which aimed to elect members of the Constituent Assembly and members of the People's Representative Council as stipulated in Law Number 7 of 1953 concerning the Election of Constituent Members and Members of the House of Representatives. Based on Article 36 of Law Number 7 of 1953 concerning the Election of Constituent Members and Members of the House of Representatives, it is stated that those who can run or be elected in the General Election are individuals (individual candidates) or candidates in groups (group candidates). The participation of political parties and local political parties can be included in the definition of a candidate pool.

Herbert Feith recorded well the election in 1955. Feith divides the four groups that participated in the election. Namely the major parties PNI, Masyumi, NU, and PKI,), intermediate parties (PSII, Parkindo, Catholic Party, PSI, Perti, IPKI), groups small groups with national coverage (PRN, Labor Party, GPPS, PRI, PPPRI, Murba Party, Baperki, PIR, Permai, PIR, PPTI, Acoma), and small groups covering regions. According to Feith, the latter group can be categorized as a regional party or group (now known as the local political party). The small group that covers the area is:[27]

a. Gerinda - Yogyakarta.

b. Partai Persatuan Dayak - Kalimantan Barat.

c. Angkatan Kesatuan Umat Islam (AKUI) - Madura.

d. Partai Rakyat Desa - Jawa Barat.

e. Partai Republik Indonesia Merdeka - Jawa Barat.

f. R. Soedjono Prawirosoedarso dan Kawan-kawan - Madiun.

g. Gerakan Pilihan Sunda - Jawa Barat.

h. Partai Tani Indonesia - Jawa Barat.

i. Raja Keprabonan dan kawan-kawan - Cirebon, Jawa Barat.

j. Gerakan Banteng - Jawa Barat.

k. Persatuan Indonesia Raya (PIR) Nusa Tenggara Barat - Lombok.

1. Panitia Pendukung Pencalonan L. M. Idrus Effendi (PPLM Idrus Effendi) -Sulawesi Tenggara. 
The The only tribal group that succeeded in the general elections for Parliament was the Persatuan Daya Party of West Kalimantan. The PRD (Partai Rakyat Desa) and PRIM (Partai Rakyat Indonesia Merdeka, Free Indonesian People's Party), although not explicitly ethnic or regional, are parties from one region, West Java. It can also be said to include AKUI (Madura), Gerinda (Yogyakarta), and R. Soedjono and friends (Madiun). All of the six political organizations that succeeded in constituent elections, but did not succeed in the elections for Parliament, were ethnic or regional in some way [28].

In a more contemporary context, today's only local political parties are local political parties in Aceh. A local political party's idea as a solution to solving the conflict in Aceh did not appear for the first time in the Helsinki negotiations. During negotiations between Indonesia and the Free Aceh Movement (GAM), mediated by the Henry Dunant Center in early 2001, a political settlement emerged in the Provisional Understanding. In the list of political substances that will discuss further (Indicative Elements for Discussion) contained in the annexed (attachment) Provisional Understanding, it is stated, among others: organizing free and fair elections for Aceh; regulations guaranteeing that non-party candidates can participate or that local-based parties can be formed in Aceh; and the criteria that would allow GAM and supporters of independence to fully participate in the political process, including transforming its political objectives through democratic means [29].

The issue then re-emerged in the Helsinki Peace Agreement which outlined in the Helsinki MoU. Local political parties then accommodated in Law Number 11 of 2006 concerning Aceh Governance. The provisions on local political parties included in Chapter XI on the Local Political Parties. In particular, Article 75 Paragraph (2) states that:

Local political parties must be established by Indonesian citizens, and have at least 50 Indonesian citizens, who are at least 21 years old, have permanent residence in Aceh, and ensure women's representation of up to $30 \%$ per cent in the legislative body.

Meanwhile, Article 75 Paragraph (8), regulates registration and legalization of political parties, stipulates that local political parties must have an organizational structure, covering at least $50 \%$ of districts and cities, and located in $25 \%$ of sub-districts in each district and city. Seeing the legality of the establishment of local political parties, as mentioned in Article 75 Paragraph (2) and (8), Law Number 11 of 2006 concerning Aceh Government shows that the procedure for the formation of local political parties in Aceh is equivalent to that for the construction of political parties at the national level. However, the mechanism for the construction of local political parties in Aceh is on a regional scale [30].

Furthermore, there are concerns that the formation of local political parties has indeed arisen since the idea of its formation. If traced further back, concerns over the consequences of forming local parties are closely related to the concept of decentralization. Decentralization has two dual sides, namely as a conflict deterrent and as a conflicted agent. [31] Therefore, to avoid the side of conflict agents (sources of conflict) with local political parties, Article 9 and Article 10 of Law Number 2 of 2008 state that:

a. The principles of political parties must not conflict with Pancasila and the 1945 constitution of the Republic of Indonesia;

b. Political parties must aim to safeguard and protect the integrity of the Unitary State of the Republic of Indonesia.

The state is justified in banning separatist and pro-independence parties that are antidemocratic, fascist or violent. For example, in France, Article 4 of the French Constitution states that all political parties must respect the principle of national sovereignty. Therefore, in 
the 1970s the highest administrative court, the Conseil d'Etat, supported parties or groups' dissolution based solely on separatism (regarding the Corsica Islands and the French Basque region) the group did not commit violent behaviors. However, according to Sullivan, if a country is fully democratic, respects human rights and has implemented the correct form of regional autonomy, then the desire for independence will decline [32].

\section{The Constitutionality of Local Parties after the Constitutional Court Decision}

In assessing the constitutionality of local parties in Papua, the Constitutional Court (hereinafter: The Court) first gave a view on special autonomy for the Papua Province. In its consideration, the Court stated:

[3.13.1] That, the special autonomy Papua (including West Papua Province as stipulated in Law No. 35 of 2008 concerning the Stipulation of Government Regulation in Law No. 1 of 2008 on the Amendment of Act No. 21 of 2001 on Special Autonomy for Papua Province Being Law) was given under Law 21 of 2001. The granting of special autonomy status for Papua is an implementation of the mandate of the Decree of the People's Consultative Assembly Number IV/MPR/1999 concerning the Outlines of State Policy for 1999-2004, which states that the national integration is maintained within the Unitary State of the Republic of Indonesia while respecting equality and diversity of life. Irian Jaya social culture through the establishment of a special autonomous region governed by the laws [vide Chapter IV letter G numbers 2].

In addition, in the People's Consultative Assembly Decree Number IV/MPR/2000 concerning Policy Recommendations in the Implementation of Regional Autonomy, among other things emphasizes the importance of immediately realizing special autonomy through the stipulation of a special autonomy law for Irian Jaya Province by taking into account the aspirations of the people at the latest May 1, 2010. In addition to the two Decrees of the People's Consultative Assembly above, the special autonomy of Papua Province including West Papua Province which is granted based on Law 21 of 2001 is also a mandate for the implementation of Article 18B paragraph (1) of the 1945 Constitution which states, "The State recognizes and respects the local government units are special or that are regulated by law ".

Thus, the granting of special autonomy for Papua is part of state recognition of the special form of a region within the framework of the Unitary State of the Republic of Indonesia, as described in the General Elucidation of Law 21/2001, among others, as follows:

"The Special Autonomy for the Papua Province is the granting of broader authority to the province and the people of Papua to regulate and manage themselves within the Unitary State of the Republic of Indonesia. The more expansive authority also means greater responsibility for the province and the people of Papua to organize the government and regulate the use of natural resources in the Papua Province for the greatest possible prosperity of the Papuan people as part of the Indonesian people following the laws and regulations." [33].

[3.13.2] That, an area designated as a special area if the local specificities and needs related to the political reality because of the position and the circumstances require that an area be given a special status that cannot be equated with other regions. In other words, there is a background to the formation and a real need so that the specificity of the region concerned is needed as part of the Unitary State of the Republic of Indonesia. Therefore, in determining the type and scope of specificity based on the background of the formation and the real needs 
that require specificity to a region, it is flexible following the real needs of the specificity of the region concerned (vide Constitutional Court Decision Number 81/PUU-VII/2010 dated March 2, 2011]. In the context of Papua, namely by remembering that to reduce the gap between Papua Province and other Provinces, and improve the standard of living of the people in the Papua Province, as well as provide opportunities for indigenous Papuans, it is necessary to have a special policy within the framework of the Unitary State of the Republic of Indonesia. "Considering" letter h of Law 21/2001] [33].

The Court further argued that if it was related to the specificities of the Papua Province, then the specificity given to the legislators to the Papua Province was in the fields of governance and politics, in the form of:

a. The Papuan People's Assembly (MRP), which is a cultural representation of indigenous Papuans who have a certain authority in the framework of protecting the rights of indigenous Papuans, is based on respect for cultural customs, empowering women, and strengthening religious harmony (Article 5 paragraph (2) Law 21 of 2001];

b. The Papua People's Representative Council (DPRP) is a terminology that is different from other regions in Indonesia, namely the provincial DPRD. Likewise, there are differences in the recruitment of DPRP members, namely that some members are appointed, while others elected through general elections [Article 6 paragraph (2) Law 21 of 2001];

c. The existence of a Special Regional Regulation (Perdasus) in addition to the Provincial Regulation (Perdasi), in the framework of implementing particular articles in this Law;

d. The difference in terminology, namely the existence of a district which is a sub-district in another province [Article 3 paragraph (2) Law 21 of 2001];

e. Governor and deputy governor Candidates must be native Papuans [Article 12 paragraph a Law 21 of 2001].

Based on these considerations, the Court concluded that local political parties were not part of Papua's specialization. In the political field, Papua's specialization is to prioritize indigenous Papuans in political recruitment as reflected in Article 28 paragraph (3) of the Papua Special Autonomy Law and the obligation to request MRP consideration as in Article 28 paragraph (4) of the Papua Special Autonomy Law. This specificity is indeed different from that given to Aceh. However, there are local political parties, their recruitment not regulated by law but is carried out independently by political parties. The Court argued, the difference based on a real need in the area, so different settings cannot be interpreted as a rule, discriminatory.

The Court based his opinion on the debate around the Papua Special Autonomy Bill discussion initiated by the House of Representatives. in the bill, the regulation on political parties regulated in Article 24 of the bill which states [34]:

a. The Papuan Resident have the right to form political parties;

b. The procedure for forming a Political Party and participating in the General Election is under statutory regulations;

c. Political recruitment conducted by political parties in Papua province should prioritize indigenous Papuans;

d. Political parties are required to ask the Papuan People's Assembly (MRP) for consideration in the selection and recruitment of their respective parties;

The Court argued there has been a substantive shift in the pattern of formulation of these norms. According to the Court, there was a change in the word entitled to become a word 
which resulted in a change from something close to being imperative to being facultative. It means that the choice of norms does not clearly mean local political parties. These norms must still be linked to the Political Party Law. Unlike the case with the Aceh Governance Law, the existence of local political parties is explicitly mentioned in the provisions of Article 1 number 14 of Law 11/2006. Not only this mention, Law 11/2006 also describes in detail the local political parties in a special chapter, namely Chapter XI Article 75 to Article 95 of Law 11 of 2006.

Before passing the decision, the Court views the possible establishment of local political parties in Papua. The Court did not get the confidence that the phrase "political party" in the Papua Special Autonomy Law is a local political party. However, suppose there is an opportunity to make changes to the law. In that case, legislators can precisely regulate the management of political parties in Papua, allowing citizens of Papua to have a more significant opportunity to be involved in managing national political parties in Papua. Furthermore, even if local political parties will be made part of Papua's specialty, legislators can also make changes to the law as long as they pay attention to Papua's real needs and are still aimed at maintaining the integrity of the Unitary State of the Republic of Indonesia.

\section{Conclusion}

Asymmetric decentralization is a policy option widely used throughout the world in managing local governments, especially aimed at maintaining the integrity of state sovereignty. The Indonesian Constitution implements asymmetric decentralization known as a special and special region as referred to in Article 18B of the 1945 Constitution. In many countries, this asymmetric decentralization also followed by an asymmetric party system which in addition to recognizing national parties, there are also local parties.

Regional political organizations, including local political parties, have participated in Indonesia's first elections in 1995. However, there were no more local parties participating in the elections after that until the enactment of the Law on Governing Aceh which allowed local political parties to exist in the 2009 elections. Papua as a special autonomy region has also initiated local political parties, but has never been successful in being involved in the elections.

Finally, the Papuan Party united to submit a judicial review of the Papua Special Autonomy Law to the Constitutional Court. The Constitutional Court stated that local political parties were not part of the specialty of Papua. However, the Constitutional Court believes that the formation of laws can regulate the existence of local political parties, so it can be said that the existence of local political parties in Papua is an opened legal policy.

\section{Acknowledgments}

The author[s] would like to thank the Center for Research and case Analysis, the constitutional Court of the Republic of Indonesia for providing support both morally and materially.

\section{References}

[1] Budiarjo, M.: Dasar-dasar llmu Politik, pp.404, Gramedia, Jakarta (2008)

[2] Ashiddiqie, J.: Pokok-pokok Hukum Tata Negara Indonesia Pasca Reformasi, pp. 71, PT BIP, Jakarta (2007)

[3] Budiarjo, M.: Pengantar Ilmu Politik, pp. 163-164, Gramedia, Jakarta (2000) 
[4] Rifai, A et. al.: Partai Politik Demokrasi Dan Kebijakan Publik, pp. 11, Averroes Press, Malang (2010)

[5] Karsayuda, R.: Pembentukan Partai Politik Lokal, pp.4, UB Press, Malang (2013)

[6] Huda, N.: Hubungan Pengawasan Produk Hukum Daerah Antara Pemerintah dan Pemerintahan Daerah Dalam Negara Kesatuan Republik Indonesia, pp.64, Disertasi, Fakultas Hukum Program Pascasarjana Universitas Islam Indonesia, Yogyakarta (2006)

[7] van Der Pot, C.W.: Handboek van het Nederlandse staatsrecht, W.E.J.Tjeenk Willink, Zwolle (1950)

[8] Manan, B.: Menyongsong Fajar Otonomi Daerah, pp.7, Pusat Studi Hukum FH-UII, Yogyakarta (2005)

[9] Muntoha, Otonomi Daerah Dan Perkembangan Peraturan-Peraturan Daerah Bernuansa Syari'ah, pp.196, Disertasi Fakultas Hukum UI, Jakarta.

[10] JPP-UGM, Desentralisasi Asimetris di Indonesia: Praktek dan Proyeksi, Jurusan Politik dan Pemerintahan Fisipol UGM, Yogyakarta (2010)

[11] Kurniadi, B.D.: Desentralisasi Asimetris di Indonesia. In Makalah disampaikan dalam Seminar di Lembaga Administrasi Negara (LAN) Jatinangor, 26 November 2012.

[12] Djojosoekarto, A., et. al (eds.).: Kinerja Otonomi Khusus Papua, Kemitraan Bagi Pembaruan Tata Pemerintahan di Indonesia, Jakarta (2008)

[13] Cornelis, L., et. Al.: Keistimewaan Yogyakarta. Monograph on Politics and Government, Vol. 2, No. 1, pp.1-122. (2008)

[14] Yuniar, A. R.: Penolakan Spanyol Terhadap Deklarasi Kemerdekaan Daerah Otonomi Catalonia Tahun 2017, Skripsi Universitas Muhammadiyah Yogyakarta, Yogyakarta (2018)

[15] Tambunan, E. M. B.: Jalan Demokratis Menuju Pemisahan Diri Belajar dari Pengalaman Quebec, in (2003).

[16] Jati, W. R.: Inkonsistensi Paradigma Otonomi Daerah di Indonesia: Dilema Sentralisasi atau Desentralisasi, Jurnal Konstitusi, Vol. 9, No. 4, pp. 751 (2012)

[17] Budiardjo, M.: Dasar-Dasar Ilmu Politik, Cetakan Kedua Puluh Tujuh, pp. 404, Gramedia Pustaka Utama, Jakarta (2005) Ibid, pp. 403-404.

[18] Hamid, A. F.: Partai Politik Lokal Di Aceh, pp. 31-33, Kemitraan, Jakarta (2008)

[19] Fadjar, A. M.: Partai Politik Ketatanegaraan Indonesia, pp. 65, Setara Pres, Malang (2013)

[20] Clark, J. C. D.: A General Theory of Party, Opposition and Government, 1688-1832, The Historical Journal, Vol. 23, No. 2, pp. 295-325 (1980)

[21] Karsayuda, R.: Pembentukan Partai Politik Lokal, pp.328-329, UB Press, Malang (2013)

[22] Gani, Y. H. A.: Self-Government Study Perbandingan Tentang Desain Administrasi Negara, pp. 9192, Paramedia Press, Jakarta (2009)

[23] Nugraha, D. P.: Partai Politik Lokal di Indonesia: Analisis Kedudukan dan Fungsi Partai Politik Lokal 1955- 2011, pp. 272, Tesis, Universitas Indonesia, Jakarta (2012)

[24] Marcet, J.: Eight years of pro-independence effort in Catalonia: elections, actors and the political process, https://www.icps.cat/archivos/Workingpapers/wp355.pdf?noga=1

[25] Fadjar, A.M.: Partai Politik Ketatanegaraan Indonesia, pp. 65-66, Setara Pres, Malang (2013)

[26] Feith, H.: Pemilihan Umum 1955 di Indonesia, pp. 89, Kepustakaan Populer Gramedia, Jakarta (1999)

[27] Nugraha, D.P.: Partai Politik Lokal di Indonesia: Analisis Kedudukan dan Fungsi Partai Politik Lokal 1955- 2011, pp. 45, Tesis, Universitas Indonesia, Jakarta (2012) Ibid, pp. 224

[28] Chapter XI about Local Political Party in Law Number11 of 2006 Concerning Aceh Governance

[29] Djumala, D.: Soft power untuk Aceh, pp. 221, Gramedia Pustaka Utama, Jakarta (2013)

[30] Sullivan, http://papuaweb.org/dlib/lap/sullivan/id/partai-lokal.rtf

[31] Constitutional Court Decision Number 41 / PUU-XVII / 2019 concerning Judicial Review of Law Number 21 of 2001 concerning Special Autonomy for Papua Province, pp. 93-94.

[32] Minutes of discussion of the Papua Special Autonomy Bill, pp. 60

[33] Prentice-Hall. Inc, 1974) 